\title{
Practical remediation of the PCB-contaminated soils
}

\author{
Akiko Ido ${ }^{1}$, Miki Niikawa ${ }^{1,2}$, Shinji Ishihara², Yoshinari Sawama², Tsuyoshi Nakanishi', Yasunari Monguchi², \\ Hironao Sajiki ${ }^{2}$ and Hisamitsu Nagase ${ }^{1 *}$
}

\begin{abstract}
A practical method for the elimination of PCBs from PCB-contaminated soil has been developed by the combination of Soxhlet extraction using a newly-developed modified Soxhlet extractor possessing an outlet valve on the extraction chamber with the chemical degradation. Various types of PCBs contaminated in soils could be completely extracted in refluxing hexane, and the subsequent hydrodechlorination could also be completed within $1 \mathrm{~h}$ in a hexane-MeOH $(1: 5)$ solution in the presence of $\mathrm{Pd} / \mathrm{C}$ and $\mathrm{Et}_{3} \mathrm{~N}$ under ordinary hydrogen pressure and temperature without the transfer of the extracted PCBs to other reaction container (a complete one-pot procedure). The present system is quite useful as a simple, safe, mild and reliable remediation method of PCB-contaminated soil.
\end{abstract}

Keywords: Remediation, PCB-contaminated soil, Soxhlet extraction, Palladium on activated carbon (Pd/C), Hydrodechlorination

\section{Introduction}

Polychlorinated biphenyls (PCBs) were commercially produced as mixtures of 209 possible congeners beginning in 1929 through the mid-1970s and are non-polar chlorinated hydrocarbons with a biphenyl nucleus, on which one to ten hydrogen atoms have been replaced with chlorine atoms. PCBs were mainly used as electric insulating oils, lubricants, and coolants in electrical devices, such as transformers and capacitors, all over the world due to their chemical and thermal stabilities. However, their production, import and novel use were banned during the mid-1970s, as such properties led to serious environmental pollution including bioaccumulations and biomagnifications through the food chain [1-4]. While PCBs in general could be decomposed by combustion using high-temperature incinerators (above $1100^{\circ} \mathrm{C}$ ), any drop in temperature below $1100^{\circ} \mathrm{C}$ creates the possibility to generate more toxic dioxins [5]; hence, it is quite difficult to reach an agreement by local communities for the construction of such incinerators. Therefore, tons of PCBs have been stored by each facility under the strict conditions in accordance with each

\footnotetext{
* Correspondence: nagase@gifu-pu.ac.jp

'Laboratory of Hygienic Chemistry and Molecular Toxicology, Gifu

Pharmaceutical University, 1-25-4 Daigaku-nishi, Gifu 501-1196, Japan

Full list of author information is available at the end of the article
}

country's laws. However, a huge expense and fear of improper disposal and accidental leaks of the PCBs, have increased with the longer periods of storage [6,7].

On the other hand, the fact is that most of the environmental PCB mass has been found in soil including marine, rivered, and lacustrine muck due to their high specific gravity and highly hydrophobic properties [8]. Although many methods for the remediation of PCBpolluted soils have been reported in the literature, such as ultrasonication $[9,10]$, photochemical degradation [11-13], reductive dechlorination using metals [14-16], base-catalyzed decomposition [17-19], hydrogen-transfer hydrodechlorination $[20,21]$, and fungous and bacterial treatments [22-25], most of these remediation methods require severe reaction conditions, such as high heat, high pressure and/or strongly basic conditions, due to the superior chemical stability of PCBs and the difficulty of complete extraction from the contaminated soil due to the strong affinity between the PCBs and soil based on a hydrophobic interaction. While direct methods for the PCB degradation without the PCB-extraction process from soil have been reported [13,18,19,22-25], a PCB extraction process was involved in most remediation parts for the reliable and reproducible PCB clean up using chemical degradation methods [9-11,14-16]. PCBs are basically extracted from their polluted soils 
by the separatory funnel method using dichloromethane [16] or hexane-acetone [15], the ultrasonic extraction method in a hexane-acetone mixed solvent [14], and the Soxhlet extraction method [11,26-28]. The United States Environmental Protection Agency (U.S. EPA) recommends Soxhlet extraction using hexane and acetone $(1: 1, \mathrm{v} / \mathrm{v})$ as a standard method to isolate PCBs from soil samples [26,27]. The Soxhlet extraction using toluene as a solvent was adopted as an official method to survey the dioxin concentration including co-planar PCBs in soil samples by the Ministry of the Environment of the Japan government [28].

We recently established an efficient method for the palladium on carbon $(\mathrm{Pd} / \mathrm{C})$-catalyzed hydrodechlorination of aromatic chlorides using triethylamine $\left(\mathrm{Et}_{3} \mathrm{~N}\right)$ as a single electron donor at ambient temperatures and pressures $[29,30]$, which has been successfully used for the degradation of dichlorodiphenyltrichloroethanes (DDTs) [31] and PCBs [32,33] based on the removal of the chlorine atoms from the aromatic nuclei, and a pilot study using a $50 \mathrm{~L}$ vessel for the practical PCB degradation was achieved [34]. Furthermore, magnesium metal was also used as a single electron donor instead of $\mathrm{Et}_{3} \mathrm{~N}$ for the $\mathrm{Pd} / \mathrm{C}$-catalyzed $\mathrm{PCB}$ degradation methods $[35,36]$.

In this paper, we describe an easy and reliable remediation method of PCB-polluted soils by PCB extraction and continuous $\mathrm{Pd} / \mathrm{C}-\mathrm{Et}_{3} \mathrm{~N}$-mediated complete hydrodechlorination of the extracted PCBs.

\section{Methods}

\section{Materials}

Quartz sand, diatomaceous earth, and bentonite were purchased from Nacalai Tesque, Inc. (Kyoto, Japan), and the silica sand (30-50 mesh) was purchased from Koso Chemical Co., Ltd. (Tokyo, Japan). The soil samples, Akadama-tsuchi and Kanuma-tsuchi, are clean, nonpollutant, mildly acidic, and produced in Tochigi prefecture, Japan. They were purchased as $2 \mathrm{~L}$ packs from Tachikawa Heiwa Nouen Co., Ltd. (Tochigi, Japan). The soil was ground by a mortar and pestle before use. Also no contamination by PCBs of all purchased soil samples (quartz sand, diatomaceous earth, bentonite, silica sand, Akadama-tsuchi and Kanuma-tsuchi) was confirmed by gas chromatography/mass spectrometry (GC/MS) analysis after Soxhlet extraction using hexane as an extraction solvent.

Aroclor 1242 was previously manufactured by the Monsanto Chemical Co. (St. Louis, MO). 10\% Pd/C (K-type, wet), which contained approximately 50\% $\mathrm{H}_{2} \mathrm{O}$, and $\mathrm{Et}_{3} \mathrm{~N}$ were obtained from N.E. Chemcat Co., Ltd. (Tokyo, Japan) and Wako Pure Chemical Industries, Ltd. (Osaka, Japan), respectively. Both hexane and $\mathrm{MeOH}$ were purchased from Nakalai Tesque, Inc. [Product number: 04338-93 (hexane) and 04338-41 (MeOH), Kyoto, Japan]. All other reagents were purchased from commercial sources and used without further purification.

A Soxhlet extractor, which has an outlet valve on the extraction chamber, was designed for the easy removal of the collected (distilled) solvents without taking apart the Soxhlet extraction setup (Figure 1).

\section{Preparation of PCB-contaminated soils}

A diethyl ether solution of Aroclor $1242(1 \mathrm{mg} / \mathrm{mL})$ was spread evenly to the purchased typical soil (quartz sand, silica sand, diatomaceous earth, bentonite, Akadama-tsuchi or Kanuma-tsuchi) to prepare the PCB-contaminated soils $(250 \mu \mathrm{g} \mathrm{PCBs} / \mathrm{g})$. Each PCB-contaminated soil was stored at $35^{\circ} \mathrm{C}$ (oil bath) for $0.5-1 \mathrm{~h}$ to allow evaporation of the diethyl ether.

\section{PCB extraction from PCB-contaminated soils using Soxhlet extractor}

Figure 2, Entry 1: The Soxhlet extraction of PCBs from the PCB-contaminated quartz sand (30 g), which was placed in the extraction thimble, was conducted using

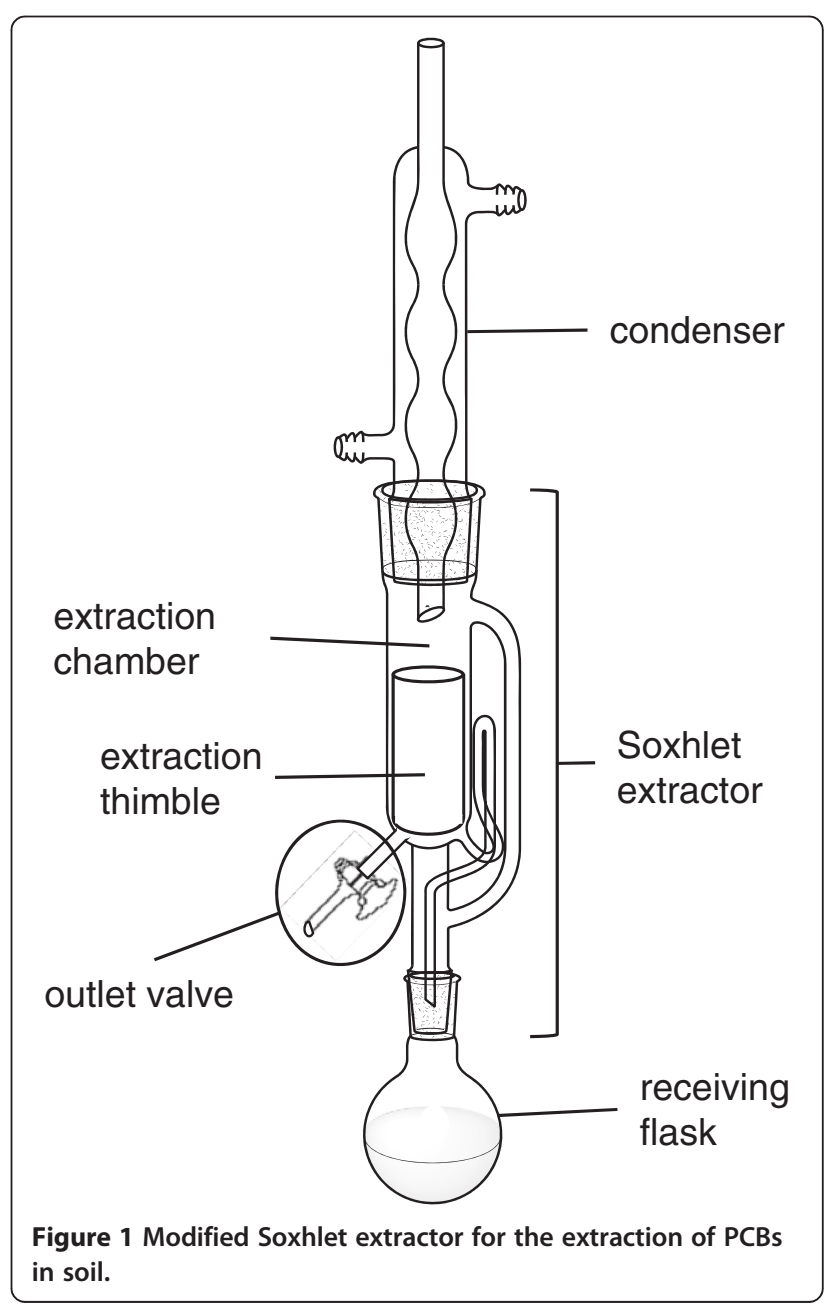




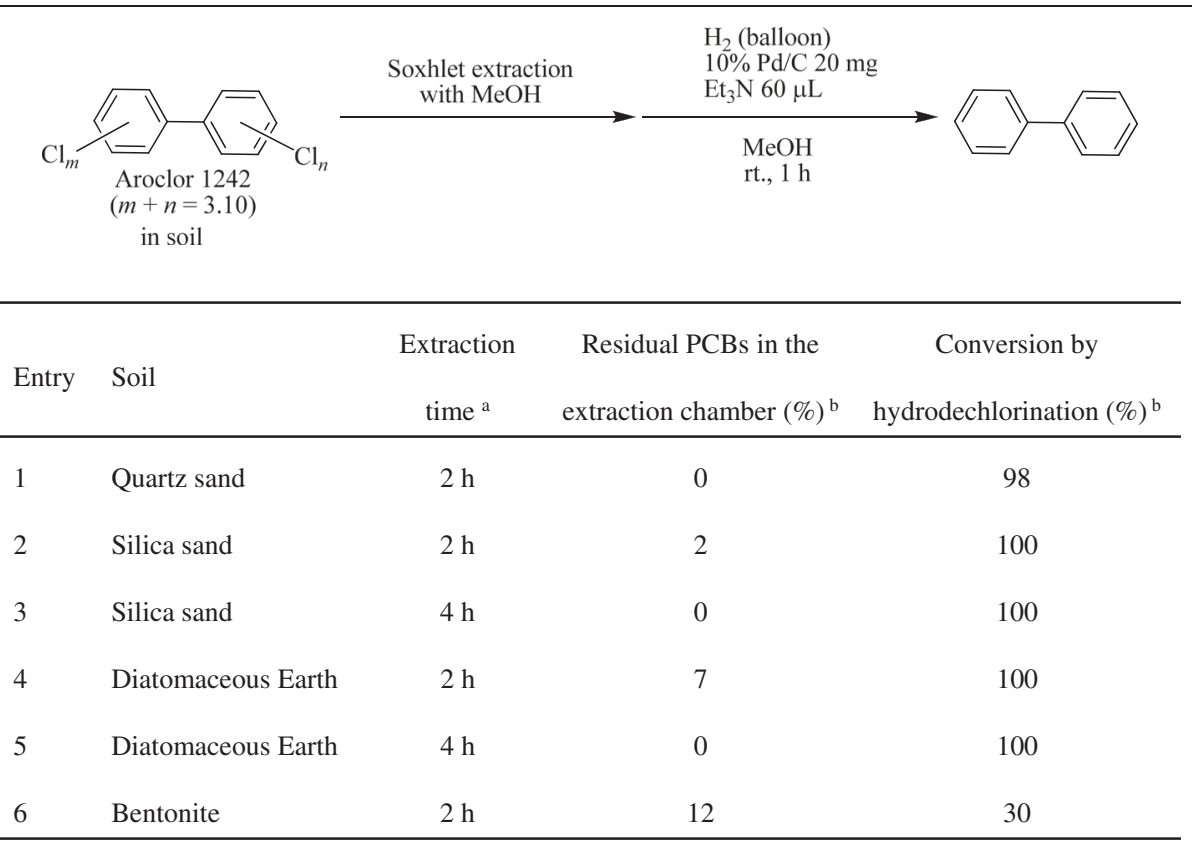

Figure 2 PCB extraction from PCB-contaminated soils with $\mathrm{MeOH}$ and hydrodechlorination under $10 \% \mathrm{Pd} / \mathrm{C}-\mathrm{Et}_{3} \mathrm{~N}-\mathrm{H}_{2}$ conditions. a Using a modified Soxhlet extractor (Figure 1) b Determined by GC/MS.

$\mathrm{MeOH}(150 \mathrm{~mL})$ as an extraction solvent for $2 \mathrm{~h}$ using a modified Soxhlet extractor that has an outlet valve connected on the extraction chamber for the easy removal of the collected (distilled) solvents after completion of the extraction (Figure 1). The PCB extract in the receiving flask was then heated at $90^{\circ} \mathrm{C}$, and the distilled $\mathrm{MeOH}$ (ca. $35 \mathrm{~mL}$ ) was collected in the extraction chamber and removed through the outlet valve. The removed $\mathrm{MeOH}$ solution $(1.5 \mathrm{~mL})$ was concentrated to dryness, and the residue was dissolved in hexane $(1.5 \mathrm{~mL})$ and analyzed by GC/MS. The residual PCBs in the extraction chamber were estimated based on the comparison of the total peak area of the PCBs between the PCB contents in the original PCB-contaminated soils and the $\mathrm{PCB}$ contents in the recovered soils after extraction. A part $(1.5 \mathrm{~mL})$ of the Soxhlet extract in the receiving flask $[\mathrm{MeOH}$ solution $(100 \mathrm{~mL})]$ was also concentrated to dryness and dissolved in hexane $(1.5 \mathrm{~mL})$. The hexane solution $(800 \mu \mathrm{L})$ was diluted with additional hexane $(400 \mu \mathrm{L})$, and the GC/MS analysis was conducted to confirm the recovery of the Aroclor 1242 in the receiving flask. The recovery ratio of Aroclor 1242 was estimated to be $93 \%$ by comparison of the peak area of the prepared hexane sample using the recovered PCBs in $\mathrm{MeOH}$ in the receiving flask with the $\mathrm{PCBs}$ in the original PCB-contaminated quartz sand $(7.5 \mathrm{mg})$.

Figure 2, Entry 2: The same procedure used in Entry 1 was followed except for using silica sand ( $30 \mathrm{~g})$ in place of the quartz sand ( $30 \mathrm{~g})$.
Figure 2, Entry 3: The same procedure used in Entry 2 was followed, and the extraction time was extended to $4 \mathrm{~h}$. The silica sand in the extraction thimble was recovered and extracted again with fresh hexane $(150 \mathrm{~mL})$ using the Soxhlet extractor for $2 \mathrm{~h}$. No residual PCBs in the extraction chamber and receiving flask were detected by GC/MS.

Figure 2, Entry 4: The procedure was the same as the method in Entry 1 except for using diatomaceous earth $(10 \mathrm{~g})$ in place of the quartz sand $(30 \mathrm{~g})$. The amount of soil was determined according to its bulkiness due to the limited volume of the extraction thimble.

Figure 2, Entry 5: The same procedure used in Entry 4 was followed, and the extraction time was extended to $4 \mathrm{~h}$. The diatomaceous earth in the extraction thimble was recovered and extracted again with fresh hexane $(150 \mathrm{~mL})$ using the Soxhlet extractor for $2 \mathrm{~h}$. No residual PCBs in the extraction chamber and receiving flask were detected by GC/MS.

Figure 2, Entry 6: The procedure was the same as the method in Entry 1 except for using bentonite $(20 \mathrm{~g})$ in place of the quartz sand $(30 \mathrm{~g})$.

Figure 3, Entry 1: The extraction procedure was the same as the method in Figure 2, Entry 1 except for the use of hexane $(150 \mathrm{~mL})$ as an extraction solvent and a 1-h extraction time. The PCB extract in the receiving flask was heated at $90^{\circ} \mathrm{C}$, and the distilled hexane (ca. $35 \mathrm{~mL}$ ) was collected in the extraction chamber and removed through the outlet valve. The removed hexane solution 


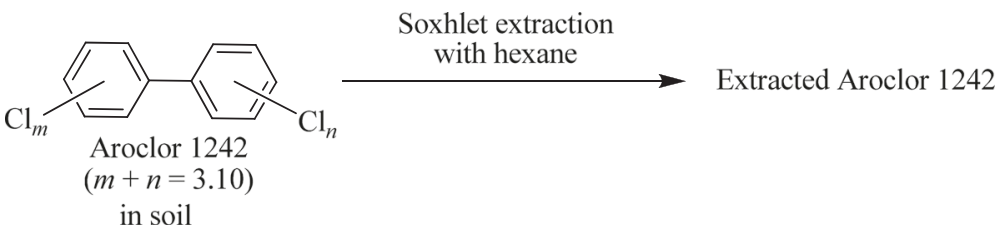

\begin{tabular}{llcc}
\hline & & & \multicolumn{2}{c}{ Residual PCBs } \\
Entry & Soil & Extraction time & in the extraction chamber $(\%)^{\mathrm{a}}$ \\
\hline 1 & Quartz sand & $1 \mathrm{~h}$ & 0.2 \\
$2^{\mathrm{b}, \mathrm{c}}$ & Quartz sand & $2 \mathrm{~h}$ & 0 \\
$3^{\mathrm{c}}$ & Silica sand & $2 \mathrm{~h}$ & 0 \\
$4^{\mathrm{c}}$ & Diatomaceous Earth & $2 \mathrm{~h}$ & 0 \\
$5^{\mathrm{n}}$ & Bentonite & $2 \mathrm{~h}$ & 3 \\
$6^{\mathrm{c}}$ & Bentonite & $4 \mathrm{~h}$ & 0 \\
$7^{\mathrm{c}}$ & Akadama-tsuchi & $2 \mathrm{~h}$ & 0 \\
$8^{c}$ & Kanuma-tsuchi & $2 \mathrm{~h}$ & 0 \\
\hline
\end{tabular}

Figure 3 PCB extraction from PCB-contaminated soils with hexane using a modified Soxhlet extractor. a Determined by GC/MS b The extraction and hydrodechlorination of PCBs were investigated three times. $\mathbf{c}$ The extracted PCBs in the receiving flask were used for the hydrodechlorination, see Figure 7.

$(1 \mu \mathrm{L})$ from the extraction chamber was analyzed by $\mathrm{GC} /$ MS without dilution.

Figure 3, Entry 2: The extraction procedure was the same as the method for Figure 3, Entry 1 except for the extraction time $(2 \mathrm{~h})$.

Figure 3, Entry 3: The extraction procedure was the same as the method for Figure 3, Entry 2 except for the use of silica sand (30 g) in place of the quartz sand (30 g).

Figure 3, Entry 4: The extraction procedure was the same as the method for Figure 3, Entry 2 except for the use of diatomaceous earth $(10 \mathrm{~g})$ in place of the quartz sand (30 g).

Figure 3, Entry 5: The extraction procedure was the same as the method for Figure 3, Entry 2 except for the use of bentonite $(20 \mathrm{~g})$ in place of the quartz sand (30 g).

Figure 3, Entry 6: The extraction procedure was the same as the method for Figure 3, Entry 1 except for the extraction time $(4 \mathrm{~h})$ and use of bentonite $(20 \mathrm{~g})$ in place of the quartz sand $(30 \mathrm{~g})$.

Figure 3, Entries 7 and 8: The extraction procedure was the same as the method for Figure 3, Entry 2 except for the use of Akadama-tsuchi (20 g) (Entry 7) or
Kanuma-tsuchi (20 g) (Entry 8) in place of the quartz sand (30 g).

In Figure 3, Entries 2-4 and 6-8, the Soxhlet extracts in the receiving flask was used for the PCB degradation under the $10 \% \mathrm{Pd} / \mathrm{C}-\mathrm{Et}_{3} \mathrm{~N}-\mathrm{H}_{2}$ conditions using the procedure described in the method section "Hydrodechlorination of PCB extracts from PCB-polluted soils under $10 \% \mathrm{Pd} / \mathrm{C}-\mathrm{Et}_{3} \mathrm{~N}-\mathrm{H}_{2}$ conditions".

The solvent effect on the hydrodechlorination of the PCBs under $10 \% \mathrm{Pd} / \mathrm{C}-\mathrm{Et}_{3} \mathrm{~N}-\mathrm{H}_{2}$ conditions

Figure 4, Entry 1: A mixture of Aroclor 1242 (7.5 mg), $10 \% \mathrm{Pd} / \mathrm{C}(5 \mathrm{mg})$ and $\mathrm{Et}_{3} \mathrm{~N}(30 \mu \mathrm{L})$ in hexane $(60 \mathrm{~mL})$ in a round-bottom flask was vigorously stirred using a stirring bar under a hydrogen atmosphere (balloon) at ambient temperature (ca. $25^{\circ} \mathrm{C}$ ). After 1,2 , and $3 \mathrm{~h}$, the reaction mixture $(1 \mathrm{~mL})$ was sampled, filtered through a $0.45 \mu \mathrm{m}$ membrane filter (Millipore, USA), and washed with $\mathrm{H}_{2} \mathrm{O}(1 \mathrm{~mL})$. The conversion yield (\%) was determined by $\mathrm{GC} / \mathrm{MS}$ analysis of the resulting hexane solution.

Figure 4, Entry 2: The procedure was the same as the method for Figure 4, Entry 1 except for the solvent [hexane-MeOH $(1: 1,60 \mathrm{~mL})$ ] and the amount of the 


\begin{tabular}{|c|c|c|c|c|}
\hline & $\underset{\begin{array}{c}\text { Aroclor } 1242 \\
(m+n=3.10) \\
7.5 \mathrm{mg}\end{array}}{\mathrm{Cl}_{n}}$ & $\begin{array}{l}\mathrm{H}_{2} \text { (balloon) } \\
10 \% \mathrm{Pd} / \mathrm{C} 5 \mathrm{mg} \\
\mathrm{Et}_{3} \mathrm{~N} 30 \mu \mathrm{L} \\
\begin{array}{c}\text { Hexane/MeOH } \\
\text { rt., } 1,2,3 \mathrm{~h}\end{array}\end{array}$ & & \\
\hline & \multirow{2}{*}{ Reaction solvent } & \multicolumn{3}{|c|}{ Conversion $(\%)^{\mathrm{a}}$} \\
\hline & & $1 \mathrm{~h}$ & $2 \mathrm{~h}$ & $3 \mathrm{~h}$ \\
\hline 1 & Hexane & 4 & 5 & 6 \\
\hline 2 & Hexane-MeOH, $1: 1(\mathrm{v} / \mathrm{v})$ & 46 & 56 & 57 \\
\hline $3^{\mathrm{b}}$ & Hexane-MeOH, $1: 5(\mathrm{v} / \mathrm{v})$ & 98 & 100 & 100 \\
\hline 4 & $\mathrm{MeOH}$ & 100 & 100 & 100 \\
\hline
\end{tabular}

sampled reaction mixture $(1.5 \mathrm{~mL})$, which was successively washed with $\mathrm{H}_{2} \mathrm{O}(1.5 \mathrm{~mL})$. The conversion yield (\%) was determined by GC/MS analysis using the doubly diluted hexane layer.

Figure 4, Entry 3: The procedure was the same as the method for Figure 4, Entry 1 except for the solvent [hexane-MeOH $(1: 5,60 \mathrm{~mL})]$ and the amount of the sampled reaction mixture $(1.5 \mathrm{~mL})$. Hexane $(1.5 \mathrm{~mL})$ and $\mathrm{H}_{2} \mathrm{O}(1.5 \mathrm{~mL})$ were added to the sampled reaction mixture, the mixture was shaken, then the hexane layer was used for the GC/MS analysis. The GC charts after 0,1 , and $2 \mathrm{~h}$ are shown in Figure 5.

Figure 4, Entry 4: The procedure was the same as the method for Figure 4, Entry 1 except for the solvent $[\mathrm{MeOH}(60 \mathrm{~mL})]$. The reaction mixture $(1.5 \mathrm{~mL})$ was sampled, filtered, and concentrated to dryness, then the residue was dissolved in hexane $(1 \mathrm{~mL})$. The solution was washed with $\mathrm{H}_{2} \mathrm{O}(1 \mathrm{~mL})$ and the hexane layer was used for the GC/MS analysis after a double dilution.

\section{Evaluation of residual PCBs in distilled hexane in the extraction chamber after the Soxhlet extraction}

The Soxhlet extraction of PCBs from the PCBcontaminated quartz sand (30 g) using hexane $(150 \mathrm{~mL})$ was carried out for $2 \mathrm{~h}$. The extract in the receiving flask was concentrated at $90^{\circ} \mathrm{C}$. The distilled and collected hexane solution (ca. $30 \mathrm{~mL}$, first fraction) was removed from the extraction chamber through the outlet valve (Figure 1$)$, and the first fraction $(1 \mu \mathrm{L})$ was analyzed by GC/MS (Figure 6a). The remaining extract in the receiving flask was gently and further concentrated at $90^{\circ} \mathrm{C}$, the distilled and collected hexane in the extraction chamber (ca. $30 \mathrm{~mL}$ ) was removed through the outlet valve as the second fraction, and its GC/MS analysis
$(1 \mu \mathrm{L})$ was also performed (Figure 6b). Two more hexane fractions (third and fourth fractions, each ca. $30 \mathrm{~mL}$ ) were collected in the extraction chamber from the extracts in the receiving flask by heating at $90^{\circ} \mathrm{C}$, removed through the outlet valve, and analyzed using GC/MS in the same manner as described for the first and second fractions (Figure 6c and d).

\section{Hydrodechlorination of PCB extracts from PCB-polluted soils under $10 \% \mathrm{Pd} / \mathrm{C}-\mathrm{Et}_{3} \mathrm{~N}-\mathrm{H}_{2}$ conditions}

Figure 2: $10 \% \mathrm{Pd} / \mathrm{C}(20 \mathrm{mg})$ and $\mathrm{Et}_{3} \mathrm{~N}(60 \mu \mathrm{L})$ were added to the PCB extract in $\mathrm{MeOH}$ (ca. $100 \mathrm{~mL}$ ) in the receiving flask (see the method section for Figure 2, "PCB extraction from PCB-contaminated soils using Soxhlet extractor"). The mixture was vigorously stirred using a stirring bar under a hydrogen atmosphere (balloon) at ambient temperature $\left(\mathrm{ca} .25^{\circ} \mathrm{C}\right.$ ) for $1 \mathrm{~h}$. The reaction mixture (ca. $5 \mathrm{~mL}$ ) was filtered through cotton, and the filtrate $(3 \mathrm{~mL})$ was concentrated to dryness. The residue was diluted with hexane $(3 \mathrm{~mL})$ and washed with $\mathrm{H}_{2} \mathrm{O}(3 \mathrm{~mL})$. The hexane layer $(800 \mu \mathrm{L})$ was diluted with additional hexane $(400 \mu \mathrm{L})$, and the resulting hexane solution was analyzed by GC/MS to analyze the degradation.

Figure 7: Each extracted $\mathrm{PCB}$ in hexane in the receiving flask (ca. $100 \mathrm{~mL}$, see the method section for Figure 3, Entries 2-4 and 6-8, "PCB extraction from PCB-contaminated soils using Soxhlet extractor") was very gently concentrated to ca. $10 \mathrm{~mL}$ using a rotary evaporator $\left(40^{\circ} \mathrm{C}\right.$, ca. $\left.20 \mathrm{mmHg}\right)$, and no $\mathrm{PCBs}$ were detected in the hexane collected in the rotary evaporator trap [b) in Figure 8] and receiving flask [a) in Figure 8] by $\mathrm{GC} / \mathrm{MS}$. $\mathrm{MeOH}(50 \mathrm{~mL}), 10 \% \mathrm{Pd} / \mathrm{C}(20 \mathrm{mg})$, and $\mathrm{Et}_{3} \mathrm{~N}(60 \mu \mathrm{L})$ were added to the receiving flask. The 


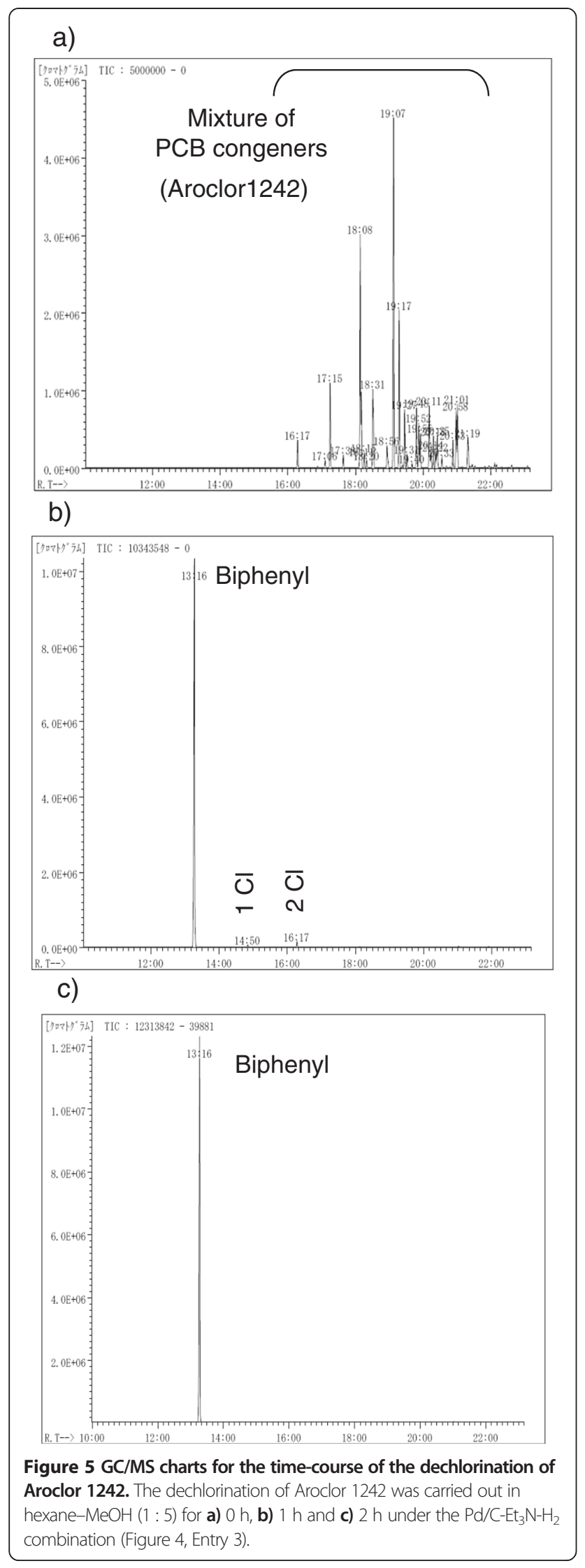

mixture was vigorously stirred using a stirring bar under a hydrogen atmosphere (balloon) at ambient temperature $\left(\mathrm{ca} .25^{\circ} \mathrm{C}\right)$ for $1 \mathrm{~h}$. The reaction mixture (ca. $6 \mathrm{~mL}$ ) was filtered through a $0.45 \mu \mathrm{m}$ membrane filter (Millipore, USA) and concentrated to dryness. The residue was diluted with hexane $(5 \mathrm{~mL})$ and washed with $\mathrm{H}_{2} \mathrm{O}(5 \mathrm{~mL})$. The hexane layer $(400 \mu \mathrm{L})$ was diluted with additional hexane $(600 \mu \mathrm{L})$, and the resulting hexane solution was analyzed by GC/MS to analyze the degradation.

\section{Instrumental analysis}

A JMS Q1000 GC [7890A gas chromatography (Agilent Technologies, USA) equipped with a JEOL MK II mass spectrometer (JEOL Co., Ltd., Japan)] and an Inert Cap $5 \mathrm{MS} / \mathrm{sil}+\mathrm{GD}$ capillary column $(30 \mathrm{~m} \times 0.25 \mathrm{~mm}$ i.d., $0.25 \mu \mathrm{m}$ film thickness: GL Science, Japan) were used for the PCB analysis. Helium was employed as a carrier gas at the flow rate of $1.3 \mathrm{~mL} / \mathrm{min}$. The injector and detector temperatures were $280^{\circ} \mathrm{C}$. The column temperature was programmed to ramp from $70^{\circ} \mathrm{C}$ (5 min hold) to $280^{\circ} \mathrm{C}$ (4 min hold) to the rate of $10^{\circ} \mathrm{C} / \mathrm{min}$. One $\mu \mathrm{L}$ of the sample solution was injected. The retention time of biphenyl was $13.01 \mathrm{~min}$ and those of the PCBs (Aroclor 1242) were 16.26-21.29 $\mathrm{min}$. The products were identified by their GC/MS retention times in comparison to those of authentic commercial samples.

\section{Results and discussion}

\section{Soxhlet extraction of PCBs from PCB-contaminated soil}

PCBs were extracted from a variety of artificially PCBcontaminated soils (quartz sand, silica sand, diatomaceous earth and bentonite) for $2 \mathrm{~h}$ using a modified Soxhlet extractor that has an outlet valve attached to the extraction chamber for the easy removal of the extraction solvent (Figure 1). $\mathrm{MeOH}$ was first examined as an extraction solvent for the present Soxhlet extraction (Figure 2), since $\mathrm{MeOH}$ was found to be an effective and preferable solvent for the $\mathrm{Pd} / \mathrm{C}$-catalyzed PCB degradation based on the dechlorination reaction in the presence of $\mathrm{Et}_{3} \mathrm{~N}$ under an $\mathrm{H}_{2}$ atomosphere [29,30,32,33]. Thus, the use of $\mathrm{MeOH}$ for the extraction could avoid the solvent exchange process for the PCB degradation after the extraction. When the 2-h Soxhlet extraction of the PCBs from the PCB-contaminated quartz sand was carried out, no PCBs were detected from the $\mathrm{MeOH}$ collected in the extraction chamber (Entry 1), and the nearly quantitative extraction of the PCBs was confirmed by the GC/MS analysis of the PCBs in the receiving flask (93\%). We determined that the PCBs were nearly quantitatively extracted in the receiving flask when no PCBs were detected in the solvents obtained from the extraction chamber after the Soxhlet extraction. Although the $\mathrm{MeOH}$ extract in the receiving flask 
a)

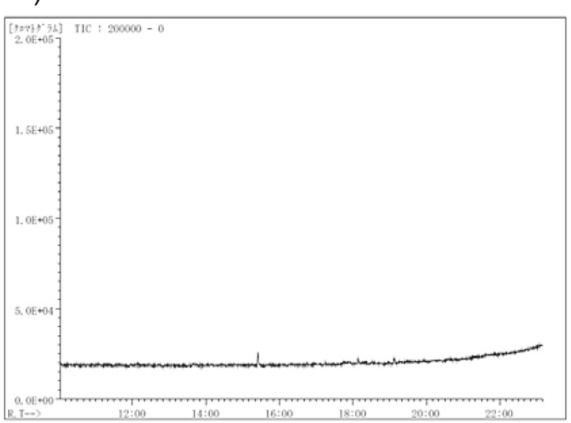

c)

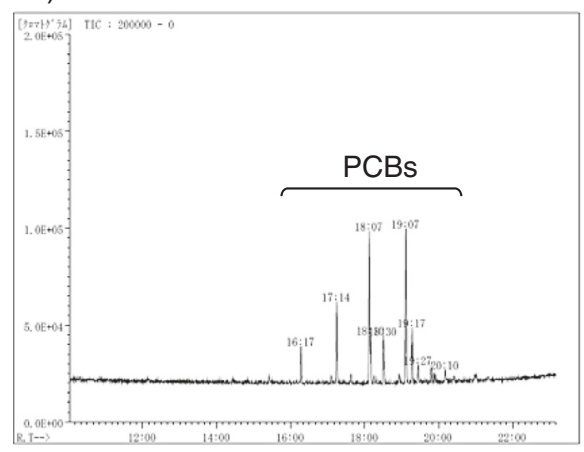

b)

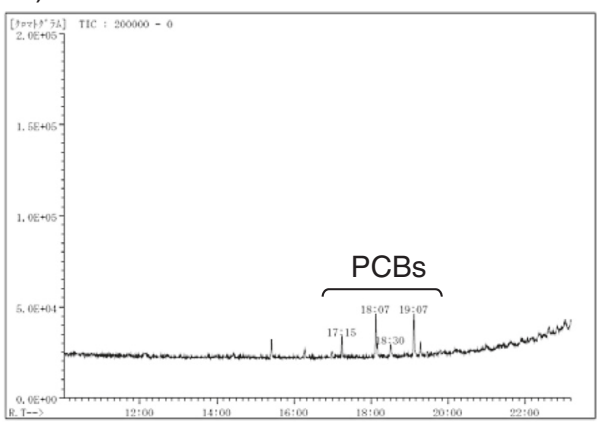

d)

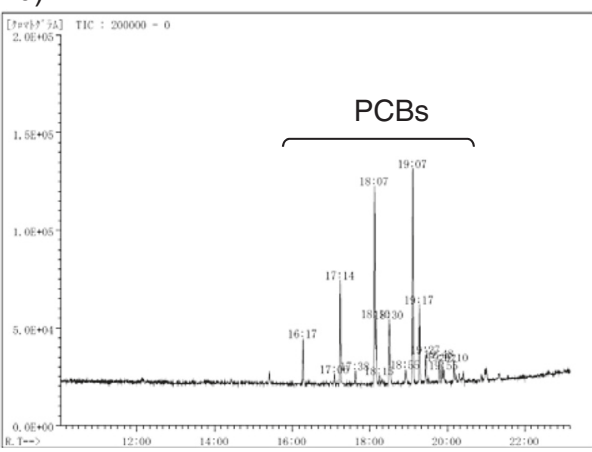

Figure 6 GC spectra of the collected hexane in the extraction chamber after the $\mathbf{2}$ h-Soxhlet extraction. a) first fraction: distilled hexane collected in the extraction chamber; b) second fraction: distilled hexane collected in the extraction chamber from the remaining hexane solution in the receiving flask after the removal of the first fraction; $\mathbf{c}$ ) third fraction: distilled hexane from the remaining hexane solution in the receiving flask after the removal of the second fraction; $\mathbf{d}$ ) fourth fraction: distilled hexane from the remaining hexane solution in the receiving flask after the removal of the third fraction.

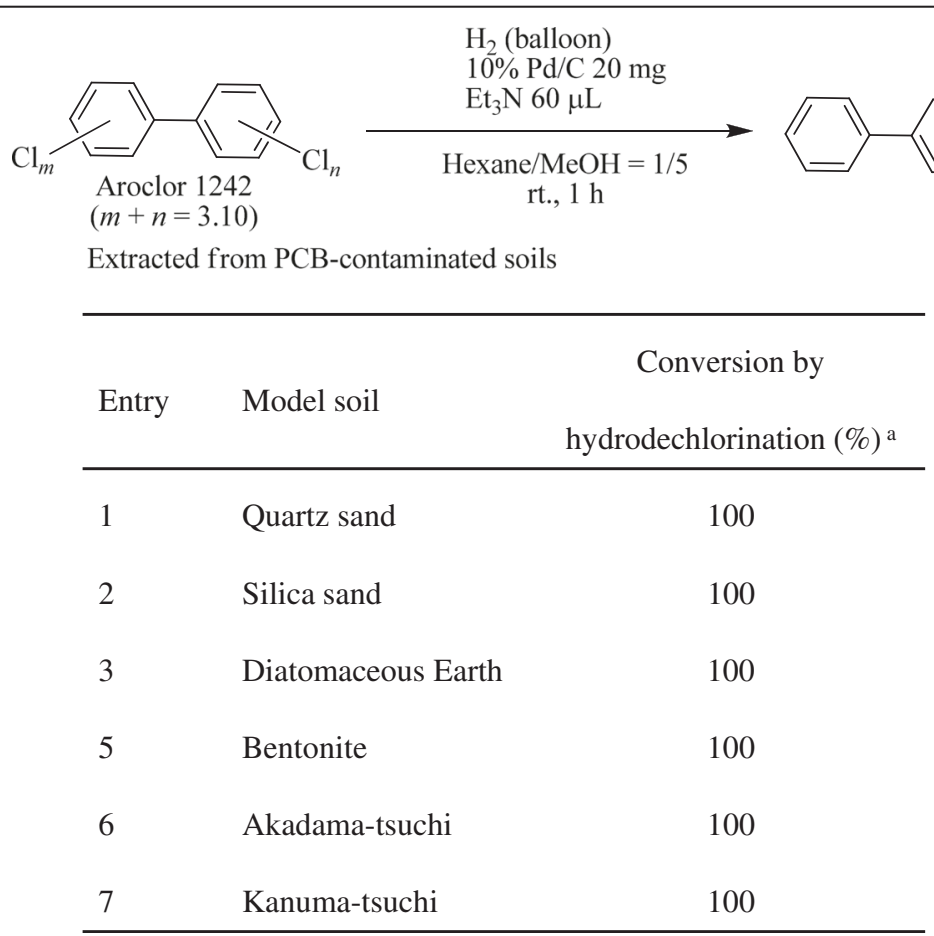

Figure 7 Hydrodechlorination of the extracted PCBs under $10 \% \mathrm{Pd} / \mathrm{C}-\mathrm{Et}_{3} \mathrm{~N}-\mathrm{H}_{2}$ conditions. a Determined by GC/MS. 


\section{a) receiving flask for solvent}

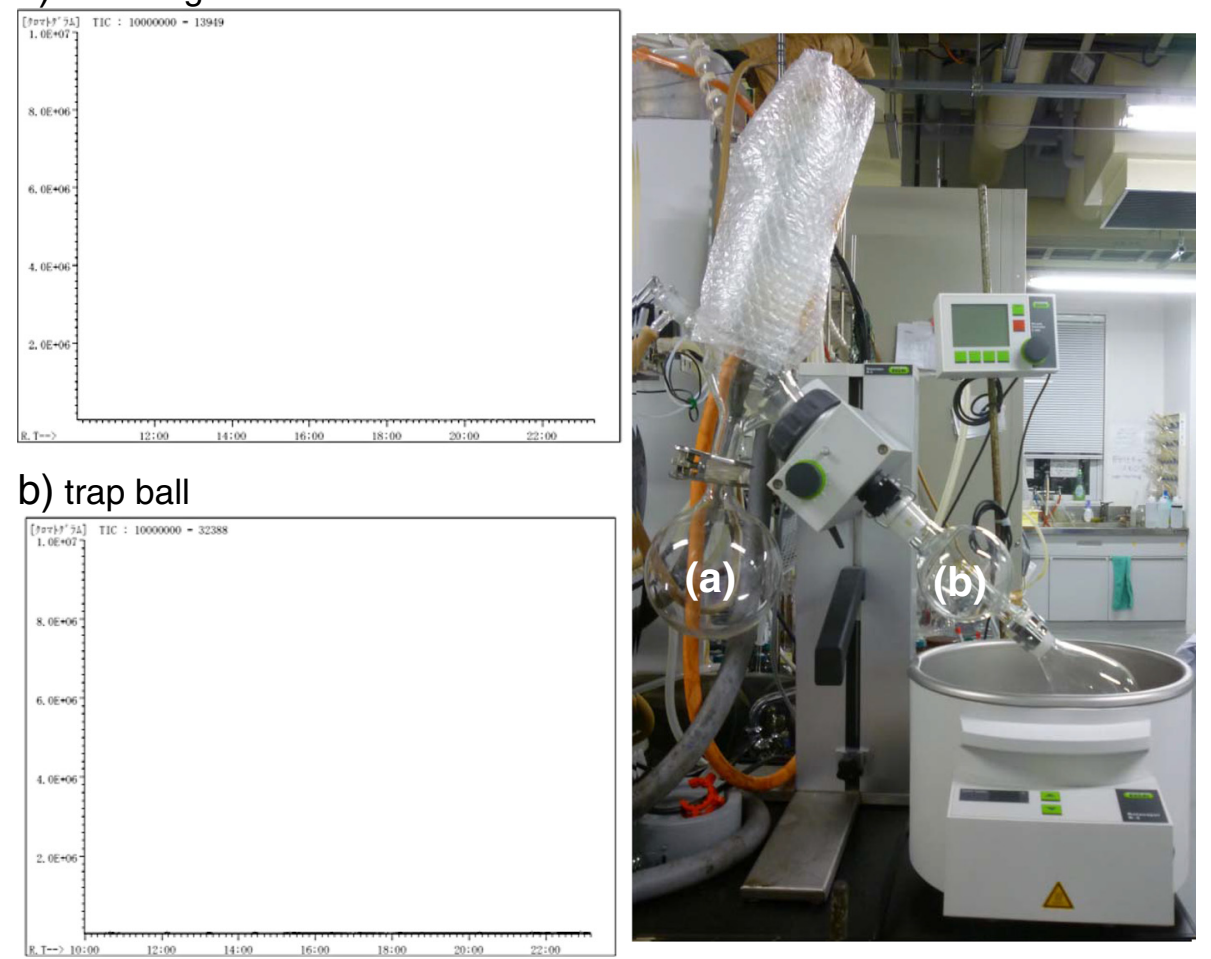

Figure 8 The GC/MS charts of the recovered hexane in the evaporator after the concentration. The GC/MS charts of the recovered hexane a) in the receiving flask (shown by (a) in the panel) and b) in the trap ball (shown by (b) in the panel) of the rotary evaporator. The panel shows rotary evaporator used in this study.

was vigorously stirred with $10 \% \mathrm{Pd} / \mathrm{C}$ and $\mathrm{Et}_{3} \mathrm{~N}$ under an $\mathrm{H}_{2}$ atmosphere (balloon) at room temperature (ca. $25^{\circ} \mathrm{C}$ ) for $1 \mathrm{~h}$, the hydrodechlorination of the PCBs in the extract was not completed (98\% conversion) contrary to our expectation. The incomplete reaction would be attributed to the sulfur contaminants in the original quartz sand, since significant amounts of sulfur contaminants $[1800 \mu \mathrm{g} / \mathrm{g}$ by the oxygen bomb combustion ion chromatography (Sumika Chemical Analytical Service, Ltd., Japan)] were extracted by $\mathrm{MeOH}$ from the quartz sand. Such sulfur components could function as catalyst poisons toward the $\mathrm{Pd} / \mathrm{C}$-catalyzed hydrodechlorination based on the significant coordination activity of sulfur atoms to palladium atoms. Therefore, $\mathrm{MeOH}$ was not an appropriate solvent for the Soxhlet extraction from the PCB-polluted quartz sand.

Although a small amount of PCBs was still extracted in $\mathrm{MeOH}$ in the extraction chamber after the 2-h extraction of the PCB-contaminated silica sand (2\%, Figure 2, Entry 2) and diatomaceous earth (7\%, Entry 4), the lengthening of the extraction time to $4 \mathrm{~h}$ certainly enhanced the extraction efficiency, and no PCBs were detected in $\mathrm{MeOH}$ in the extraction chamber (Entries 3 and 5). The soils in the extraction thimble after 4-h extraction (Entries 3 and 5) were recovered, and further extraction was conducted with fresh hexane using the Soxhlet extractor for $2 \mathrm{~h}$, since hexane was generally employed as an effective solvent for the PCB extraction $[11,14]$. Consequently, no PCBs were detected from both the extraction chamber and the receiving flask, indicating that the PCBs were completely extracted from soils by the first 4-h Soxhlet extraction. Therefore, we estimated that the complete PCB extraction was achieved when no PCBs were detected in the solvent in the extraction chamber. Furthermore, PCBs in the $\mathrm{MeOH}$ extracts of the PCB-contaminated silica sand and diatomaceous earth underwent a complete degradation under $\mathrm{Pd} / \mathrm{C}-\mathrm{Et}_{3} \mathrm{~N}$-mediated hydrodechlorination conditions (Entries 3 and 5). On the other hand, the Soxhlet extraction of the PCB-contaminated bentonite using $\mathrm{MeOH}$ was unsuccessful probably due to the strong adsorptive property, affinity for $\mathrm{MeOH}$ and/or viscosity of the bentonite, and a significant amount of PCBs (12\%) still remained in $\mathrm{MeOH}$ in the extraction chamber after 2 -h extraction. Furthermore, the subsequent $10 \% \mathrm{Pd}-$ catalyzed hydrodechlorination proceeded in only $30 \%$ (Entry 6). Bentonite is originally derived from volcanic ash and contains a substantial amount of sulfur concomitants, such as sulfates and sulfides. The sulfur materials would be extracted from the bentonite together with 
PCBs by the Soxhlet extraction with $\mathrm{MeOH}$ and strongly suppress the PCB degradation as catalyst poisons in analogy (more significantly) with the hydrodechlorination of the $\mathrm{MeOH}$ extracts of quartz sand (Entry 1). Therefore, we concluded that $\mathrm{MeOH}$ was not effective as a solvent for the Soxhlet extraction of PCBs.

Hexane has been mainly used as an efficient solvent for the extraction of PCBs from the PCB-contaminated solid materials and water in the literature $[11,14,37,38]$. Furthermore, the low solubility of sulfur contaminants in hexane is also easily predicted compared to $\mathrm{MeOH}$. Therefore, the Soxhlet extraction of PCBs with hexane from the PCB-contaminated quartz sand was carried out to establish the effective $\mathrm{PCB}$ extraction method (Figure 3, Entries 1 and 2). Although the 1-h Soxhlet extraction was incomplete for the perfect removal of PCBs from the PCB-contaminated quartz sand and $0.2 \%$ of the PCBs still remained in hexane in the extraction chamber (Entry 1), the PCB-residue completely disappeared from the extraction chamber by extending the extraction time to $2 \mathrm{~h}$ (Entry 2). The Soxhlet extraction procedure for $\mathrm{PCBs}$ with hexane was reliable since it could be reproduced three times (Entry 2), and the amounts of the extracted sulfur contaminants from the PCB-contaminated quartz sand were notably decreased compared to the extraction with $\mathrm{MeOH}$ [ $880 \mu \mathrm{g} / \mathrm{g}$ by oxygen bomb combustion ion chromatography (Sumika Chemical Analytical Service, Ltd., Japan)]. These results indicated that the PCBs were completely and selectively extracted from the polluted quartz sand by hexane. The Soxhlet extraction method using hexane could also be applied to extraction from the PCB-contaminated silica sand and diatomaceous earth (Entries 3 and 4), although the extraction of PCBcontaminated bentonite was incomplete within $2 \mathrm{~h}$ (Entry 5) probably because bentonite could strongly adsorb PCBs due to its strong viscosity property. A quantitative extraction of PCBs from PCB-contaminated bentonite was successfully achieved by extending the extraction time to $4 \mathrm{~h}$ (Entry 6).

The method for the remediation of PCB-polluted soils was also used for the cleanup of horticultural soils, Akadama-tsuchi and Kanuma-tsuchi (Entries 7 and 8). The PCBs in both the PCB-contaminated Akadama-tsuchi (Entry 7) and Kanuma-tsuchi (Entry 8) were completely extracted with hexane within $2 \mathrm{~h}$ using the modified Soxhlet extractor.

The extracted Aroclor 1242 in the receiving flask from polluted-quartz sand (Entry 2), -silica sand (Entry 3), -diatomaceous earth (Entry 4), -bentonite (Entry 6), -Akadama-tsuchi (Entry 7), and -Kanuma-tsuchi (Entry 8) were successively employed for the Pd/C-catalyzed hydrodechlorination, which will be discussed later (Figure 7).

\section{Solvent effect on the PCB dechlorination}

Since hexane was found to be appropriate as a solvent for the Soxhlet extraction of PCBs, the use of hexane as a solvent for the degradation of $\mathrm{PCBs}$ based on the hydrodechlorination of aromatic chloride under $\mathrm{Pd} / \mathrm{C}-$ $\mathrm{Et}_{3} \mathrm{~N}-\mathrm{H}_{2}$ conditions would be desired due to the safe and easy handling on the basis of no need to exchange solvents after the extraction. However, the $10 \% \mathrm{Pd} / \mathrm{C}$ catalyzed hydrodechlorination of Aroclor 1242 in the presence of $\mathrm{Et}_{3} \mathrm{~N}$ hardly proceeded in hexane (Figure 4 Entry 1). The detailed study of the $\mathrm{Pd} / \mathrm{C}$-catalyzed hydrodechlorination in the presence of $\mathrm{Et}_{3} \mathrm{~N}$ under an $\mathrm{H}_{2}$ atmosphere has already revealed that $\mathrm{MeOH}$ was an effective and preferable solvent [29,30,32,33]. Aroclor 1242 was completely hydrodechlorinated at room temperature within $1 \mathrm{~h}$ in $\mathrm{MeOH}$ instead of hexane (Entry 4). The mixed solvent of hexane and $\mathrm{MeOH}$ was then investigated, since the complete removal of hexane from the receiving flask for the exchange of solvents after the Soxhlet extraction includes the risk of the possible evaporation or leak of PCBs together with hexane (see the discussion in the section "Procedure for the concentration of the PCB extract in the receiving flask"). The higher $\mathrm{MeOH}$ ratio of the mixed solvents more effectively promoted the hydrodechlorination (Figure 4 Entries 2 and 3), and it could be completed in hexane$\mathrm{MeOH}(1: 5)$ within $2 \mathrm{~h}$ under ambient pressures and temperatures (Entry 3) as shown in Figure 5.

\section{Concentration of the $\mathrm{PCB}$ extract in the receiving flask}

We next investigated the establishment of a procedure for the removal of hexane from the Soxhlet extract in the receiving flask for the subsequent $\mathrm{Pd} / \mathrm{C}$-catalyzed hydrodechlorination of PCBs in hexane-MeOH $(1: 5)$. After the 2-h Soxhlet extraction of PCBs from the PCBcontaminated quartz sand using hexane, the hexane was transferred to the extraction chamber from the receiving flask by the four-step distillation, and collected as different fractions (Figure 6). Although no PCBs were detected in the first fraction (Figure 6a), a small quantity of PCBs was found in the 2nd fraction (Figure 6b), and the detected PCB quantity increased in a fraction-number-dependent manner (Figure $6 \mathrm{~b}-\mathrm{d}$ ). These results suggest that a small amount of PCBs could be vaporized together with the distilled hexane with decreasing amount of hexane in the receiving flask even under gentle refluxing conditions. On the other hand, when the further gentle concentration of the hexane extract in the receiving flask using a rotary evaporator under reduced pressure (ca. $20 \mathrm{mmHg}$ ) at $40^{\circ} \mathrm{C}$ was done, no PCBs were detected in the collected hexane in both the rotary evaporator trap [b) in Figure 8] and the solvent receiving flask [a) in Figure 8] by GC/MS, indicating that no PCBs had been vaporized during the gentle evaporation under a sufficiently reduced pressure. 


\section{Continuous operation of the PCB extraction using the Soxhlet extractor and dechlorination using the $10 \%$ $\mathrm{Pd} / \mathrm{C}-\mathrm{Et}_{3} \mathrm{~N}-\mathrm{H}_{2}$ conditions}

The PCB extraction from a variety of PCB-contaminated soils (quartz sand, silica sand, diatomaceous earth, bentonite, Akadama-tsuchi and Kanuma-tsuchi) with hexane (Figure 3) and the subsequent dechlorination using $\mathrm{Pd} / \mathrm{C}-\mathrm{Et}_{3} \mathrm{~N}-\mathrm{H}_{2}$ conditions in hexane-MeOH were carried out under ambient $\mathrm{H}_{2}$ pressures (balloon) and temperatures (Figure 7). While the PCBs in the $\mathrm{MeOH}$ extract from the PCB-contaminated quartz sand were not completely hydrodechlorinated under $10 \% \mathrm{Pd} / \mathrm{C}-$ $\mathrm{H}_{2}-\mathrm{Et}_{3} \mathrm{~N}$ conditions (Figure 2, Entry 1), the degradation of the hexane extract (Figure 3, Entry 2) was completed (Figure 7, Entry 1) because the amount of sulfurcontaminants in the hexane extract was sufficiently low $(880 \mu \mathrm{g} / \mathrm{g})$ compared to that of $\mathrm{MeOH}(1800 \mu \mathrm{g} / \mathrm{g})$. Furthermore, all other PCB extracts derived from the silica sand, diatomaceous earth, bentonite, Akadama-tsuchi and Kanuma-tsuchi were also smoothly and completely degraded within $1 \mathrm{~h}$ (Figure 7, Entries 2-7).

The present soil remediation method using a modified (newly-developed) Soxhlet extractor that bears an outlet valve on the extraction chamber is able to extract PCBs from PCB-contaminated soils completely and the subsequent chemical degradation is successfully accomplished by a one-pot procedure. In reported remediation methods in the literature involved extraction process, the PCB extraction from soil and its chemical degradation could be achieved totally independent manner with the exchange of the reaction containers [9-11,14-16], to our knowledge. The present method is quite safe by reason that the operators could prevent the extracted PCBs from the direct contacting. Furthermore, PCBs extracted from PCB-contaminated soils quantitatively degrade based on a $\mathrm{Pd} / \mathrm{C}$-catalyzed dechlorination in the presence of $\mathrm{Et}_{3} \mathrm{~N}$ under ambient hydrogen pressure and temperature in a short time. Moreover, the $\mathrm{Pd} / \mathrm{C}$ might be recovered and reused by the simple wash in water and hexane sequentially [32]. The present remediation method achieved extensive improvement in simplicity, safety and time-efficiencies over the previously reported remediation processes.

\section{Conclusions}

We developed a practical method for the remediation of PCB-contaminated soils. One of the notable features of the PCB remediation of PCB-contaminated soils is the use of a receiving flask for the Soxhlet extractor as a reaction flask for the hydrodechlorination of PCBs. Therefore, the present remediation method never requires the transfer of the extracted PCBs to another reaction container and the degradation is successfully accomplished by a one-pot procedure. Thus, the possible secondary pollution by the extracted (concentrated) PCBs does not occur. PCBs are efficiently extracted with hexane from various types of polluted soils, and their dechlorination could be easily achieved in a hexane-MeOH $(1: 5)$ solution using the $10 \% \mathrm{Pd} / \mathrm{C}-\mathrm{Et}_{3} \mathrm{~N}-\mathrm{H}_{2}$ conditions under ambient pressures (balloon) and temperatures (ca. $25^{\circ} \mathrm{C}$ ). The present method is quite simple and would be useful for the mild and practical remediation of PCB-polluted soils.

\section{Abbreviations}

PCBs: Polychlorinated biphenyls; Pd/C: Palladium on activated carbon; $\mathrm{Et}_{3} \mathrm{~N}$ : Trimethylamine; U.S.EPA: The United States environmental protection agency; DDTs: Dichlorodiphenyltrichloroethanes; GC/MS: Gas chromatography/ mass spectrometry.

\section{Competing interests}

The authors declare that they have no competing interests.

\section{Authors' contributions}

YM, HS and HN conceived the work; Al, MN and SI performed the experiments; $\mathrm{Al}, \mathrm{MN}, \mathrm{SI}, \mathrm{YS}, \mathrm{TN}, \mathrm{YM}, \mathrm{HS}$ and HN designed the experiments and analyzed the data; and $\mathrm{Al}, \mathrm{YM}, \mathrm{HS}$ and $\mathrm{HN}$ wrote the manuscript. All authors read and approved the final manuscript.

\section{Acknowledgements}

We sincerely appreciate the support by the New Energy and Industrial Technology Development Organization (NEDO), Japan. We also thank the N.E. Chemcat Corporation for the gift of $\mathrm{Pd} / \mathrm{C}$.

\section{Author details}

'Laboratory of Hygienic Chemistry and Molecular Toxicology, Gifu

Pharmaceutical University, 1-25-4 Daigaku-nishi, Gifu 501-1196, Japan.

${ }^{2}$ Laboratory of Organic Chemistry, Gifu Pharmaceutical University, 1-25-4 Daigaku-nishi, Gifu 501-1196, Japan.

Received: 10 September 2013 Accepted: 11 January 2015

Published online: 10 February 2015

\section{References}

1. U.S. Department of Health and Human Services, Public Health Service, Agency for toxic substances and disease registry: Toxicological profile for polychlorinated biphenyls. 2000. [http://www.atsdr.cdc.gov/toxprofiles/tp17.pdf]

2. Blais JM, Schindler DW, Muir DCG, Kimpe LE, Donald DB, Rosenberg B. Accumulation of persistent organochlorine compounds in mountains of western Canada. Nature. 1998:395:585-8.

3. Epling GA, Florio EM, Bourque AJ, Qian XH, Stuart JD. Borohydride, micellar, and exciplex-enhanced dechlorination of chlorobiphenyls. Environ Sci Technol. 1988:22:952-6.

4. Erickson MD. Analytical Chemistry of PCBs. 2nd ed. Boca Raton: CRC press; 1997.

5. Tundo P, Facchetti S, Tumiatti W, Fortunati UG. Chemical degradation of 2,3,7,8-TCDD by means of polyethylene glycols in the presence of weak bases and an oxidant. Chemosphere. 1985;14:403-10.

6. The Environment Programme of the United Nations: Inventory of worldwide PCB destruction capacity; second issue. 2004. [http://www.chem.unep. ch/pops/pcb_activities/pcb_dest/PCB_Dest_Cap_SHORT.pdf]

7. Meharg AA, Osborn D. Dioxins released from chemical accidents. Nature. 1995;375:353-4.

8. Travis CC, Hester ST. Global chemical pollution. Environ Sci Technol. 1991;25:814-9.

9. Okitsu K, Yoshioka Y, Tanabe S. Effect of transition metal powder and lowenergy ultrasound frequency on degradation rate of chlorinated hydrocarbons in water. Bunseki Kagaku. 2006;55:567-71.

10. Okuno H, Yim B, Mizukoshi Y, Nagata Y, Maeda Y. Sonolytic degradation of hazardous organic compounds in aqueous solution. Ultrason Sonochem. 2000;7:261-4. 
11. Achari G, Jakher A, Gupta C, Dhol A, Langford CH. Practical method to extract and dechlorinate PCBs in soils. Pract Period Hazard, Toxic, Radioact Waste Manage. 2010;14:98-103.

12. Koshioka M, Kanazawa J, lizuka H, Murai T. Photodegradation of decachlorobiphenyl. Bull Environ Contam Toxicol. 1987;38:409-15.

13. Kouta S, Mizuki S, Wataru A, Yukio T. Photodecomposition of dioxin in ash and paddy field soil. Organohalogen Compounds. 2007;69:435/431-4.

14. He N, Li P, Zhou Y, Ren W, Fan S, Verkhozina VA. Catalytic dechlorination of polychlorinated biphenyls in soil by palladium-iron bimetallic catalyst. J Hazard Mater. 2009:164:126-32.

15. Huang $\mathrm{Q}$, Hong C-S. $\mathrm{TiO}_{2}$ photocatalytic degradation of PCBs in soil-water systems containing fluoro surfactant. Chemosphere. 2000;41:871-9.

16. Mitoma Y, Egashira N, Simion C. Highly effective degradation of polychlorinated biphenyls in soil mediated by a $\mathrm{Ca} / \mathrm{Rh}$ bicatalytic system. Chemosphere. 2009;74:968-73.

17. Noma Y, Mitsuhara Y, Matsuyama K, Sakai S-I. Pathways and products of the degradation of PCBs by the sodium dispersion method. Chemosphere. 2007;68:871-9.

18. Pittman $\mathrm{CU}, \mathrm{He} \mathrm{J}$. Dechlorination of PCBs, $\mathrm{CAHs}$, herbicides and pesticides neat and in soils at $25^{\circ} \mathrm{C}$ using $\mathrm{Na} / \mathrm{NH}_{3}$. J Hazard Mater. 2002;92:51-62.

19. Taniguchi S, Murakami A, Hosomi M, Miyamura A, Uchida R. Chemical decontamination of PCB-contaminated soil. Chemosphere. 1997:34:1631-7.

20. Ukisu Y, limura S, Uchida R. Catalytic dechlorination of polychlorinated biphenyls with carbon-supported noble metal catalysts under mild conditions. Chemosphere. 1996:33:1523-30.

21. Ukisu Y, Miyadera T. Hydrogen-transfer hydrodehalogenation of aromatic halides with alcohols in the presence of noble metal catalysts. J Mol Catal A Chem. 1997;125:135-42.

22. Wu Q, Sowers KR, May HD. Microbial reductive dechlorination of Aroclor 1260 in anaerobic slurries of estuarine sediments. Appl Environ Microbiol. 1998;64:1052-8.

23. Murinova $S$, Dercova $K$, Dudasova $H$. Degradation of polychlorinated biphenyls (PCBs) by four bacterial isolates obtained from the PCB-contaminated soil and PCB-contaminated sediment. International Biodeterioration \& Biodegradation. 2014;91:52-9.

24. Petric I, Hrsak D, Fingler S, Udikovic-Kolic N, Bru D, Martin-Laurent F. Insight in the PCB-degrading functional community in long-term contaminated soil under bioremediation. Journal of Soils and Sediments. 2011;11:290-300.

25. Song M, Luo C, Li F, Jiang L, Wang Y, Zhang D, et al. Anaerobic degradation of Polychlorinated Biphenyls (PCBs) and Polychlorinated Biphenyls Ethers (PBDEs), and microbial community dynamics of electronic waste-contaminated soil. Sci Total Environ. 2015;502:426-33.

26. U.S. Environmental Protection Agency: USEPA Method 3540C: Soxhlet extraction. 1996. [http://www.epa.gov/osw/hazard/testmethods/sw846/pdfs/ 3540c.pdf]

27. U.S. Environmental Protection Agency: USEPA Method 8028A: Polychlorinated biphenyls by gas chromatography. 2007. [http://www.epa. gov/wastes/hazard/testmethods/sw846/pdfs/8082a.pdf]

28. Ministry of the Environment of the Japan Government: Manual of the survey measurement of dioxins in soils. 2009. [http://www.env.go.jp/chemi/ dioxin/manual/dojo-manual/main.pdf] (Japanese only)

29. Monguchi Y, Kume A, Hattori K, Maegawa T, Sajiki H. Pd/C-Et $t_{3} \mathrm{~N}$-mediated catalytic hydrodechlorination of aromatic chlorides under mild conditions. Tetrahedron. 2006;62:7926-33.

30. Sajiki H, Kume A, Hattori K, Hirota K. Mild and general procedure for Pd/C catalyzed hydrodechlorination of aromatic chlorides. Tetrahedron Lett. 2002:43:7247-50

31. Monguchi $Y$, Kume A, Sajiki H. Facile and catalytic degradation method of DDT using $\mathrm{Pd} / \mathrm{C}-\mathrm{Et}_{3} \mathrm{~N}$ system under ambient pressure and temperature. Tetrahedron. 2006:62:8384-92.

32. Kume A, Monguchi $Y$, Hattori K, Nagase H, Sajiki H. Pd/C-catalyzed practical degradation of PCBs at room temperature. Appl Catal, B. 2008;81:274-82

33. Sajiki $H$, Kume A, Hattori $K$, Nagase $H$, Hirota K. Complete and truly catalytic degradation method of $\mathrm{PCBs}$ using $\mathrm{Pd} / \mathrm{C}-\mathrm{Et}_{3} \mathrm{~N}$ system under ambient pressure and temperature. Tetrahedron Lett. 2002;43:7251-4.

34. Monguchi $Y$, Ishihara S, Ido A, Niikawa M, Kamiya K, Sawama $Y$, et al. Pilotplant study of the PCB degradation at ambient temperature and pressure. Org Process Res Dev. 2010;14:1140-6.

35. Ido A, Ishihara S, Kume A, Nakanishi T, Monguchi Y, Sajiki H, et al. Practical method for PCB degradation using Pd/C- $\mathrm{H}_{2}-\mathrm{Mg}$ system. Chemosphere. 2013;90:57-64
36. Ishihara S, Ido A, Monguchi Y, Nagase H, Sajiki H. Pd/C-catalyzed dechlorination of polychlorinated biphenyls under hydrogen gas-free conditions. J Hazard Mater. 2012;229-230:15-9.

37. Adenugba AA, McMartin DW, Beck A. Environmental contamination of ready meals by polychlorinated biphenyls (PCBs). J Environ Sci and Health A Tox Hazard Subst \& Environ Eng. 2012;47:2230-40.

38. Marku E, Nuro A, Murtaj B. Polychlorinated biphenyls and organochlorine pesticide residues in drinking water of Tirana city (Albania). J Environ Prot Ecol. 2011;12:7-15.

\section{Submit your next manuscript to BioMed Central and take full advantage of:}

- Convenient online submission

- Thorough peer review

- No space constraints or color figure charges

- Immediate publication on acceptance

- Inclusion in PubMed, CAS, Scopus and Google Scholar

- Research which is freely available for redistribution 